\title{
Obesity in Childhood: Introduction and General Considerations
}

\author{
CHARLES H. HENNEKENS, WENDY R. SCHNEIDER, AND E. JOAN BARICE
}

\begin{abstract}
Department of Biomedical Science [C.H.H., W.R.S., E.J.B.], Center of Excellence, FL Atlantic University, Boca Raton, FL 33431; Departments of Medicine \& Epidemiology and Public Health [C.H.H.] and Psychiatry and Behavioral Science [E.J.B.], University of Miami Miller School of Medicine, Miami, FL 33136; Department of Preventive Medicine [C.H.H., E.J.B.], NOVA Southeastern University, Fort Lauderdale, FL 33328
\end{abstract}

$\mathrm{O}^{\mathrm{s}}$ besity in childhood is perhaps the most major clinical and public health problem in the United States and most developed countries and is rapidly becoming so in developing countries. The National Health and Nutrition Examination Survey (NHANES) is a federally funded periodic survey of a random sample of the U.S. population. In NHANES data over the past several decades, there is a 3 -fold increase in the prevalence of obesity in childhood (1-4). These data are alarming but, perhaps not surprising.

The landmark Framingham Heart Study, which enrolled and followed over 5000 residents of a single community in Massachusetts for over 40 years, has demonstrated that in middle age the average American gains about seven pounds per decade of life. Thus, for these and other cogent reasons, it appears that, at present, the adult population of the U.S. is the fattest society in the world and likely to be the fattest in the history of the world (5). Further, there are even more alarming trends in obesity in childhood in developing countries $(6,7)$. Thus, the epidemic of obesity in childhood in the United States and most developed countries is now becoming a pandemic.

This emerging pandemic results from genetic and environmental factors, chiefly increased caloric intake and physical inactivity (3,6,8-12). Further, and also not surprisingly, childhood obesity has contributed to marked increases in metabolic syndrome and type 2 diabetes in U.S. children (13-15). The increasing prevalence of metabolic syndrome and type 2 diabetes in childhood has also been well documented in developing countries, including China $(16,17)$.

Among most middle-aged adult populations, smokers tend to be thinner due to the effects of smoking on decreasing appetite and increasing basal metabolic rate. Among adolescents in both developed and developing countries, the rise in cigarette consumption is associated with increasing obesity perhaps due, at least in part, to increasing levels of physical inactivity $(12,18-20)$.

Received March 19, 2007 accepted March 23, 2007

Corresponding author: Charles H. Hennekens, M.D., Dr. P.H., Department of Biomedical Science, Center of Excellence, 2800 South Ocean Boulevard, PH-A, Boca Raton, FL 33432; e-mail: profchhmd@prodigy.net

DOI: 10.1203/PDR.0b013e3180686cf1
At present, most of the remarkable decline in mortality from coronary heart disease in the United States over the past several decades is currently due to diagnosis and treatment rather than primary prevention. Further, the rate of decline is decreasing and coronary heart disease will increase as the current generation of U.S. children and adolescents reach middle age (18). For all these reasons, cardiovascular disease (CVD) is and will remain the leading killer in the United States and most developed countries. Thus, the long-term consequences of childhood obesity could cause our current generation of children to become the first in the history of the United States to have a decreased life expectancy than their parents $(13,21)$. In addition, however, the alarming increases in obesity and tobacco consumption in developing countries has led the World Health Organization to estimate that CVD will rise from number 5 to number 1, the leading killer in the entire world after another decade $(6,7)$.

There is increasing evidence that atherosclerosis begins in childhood. In the Bogalusa Heart Study, autopsy studies of children showed a clear relationship between the number and severity of risk factors, principally obesity, with atherosclerosis in both the aorta and coronary arteries $(14,22)$. Thus, the need for primary prevention of cardiovascular disease beginning in childhood is clear $(7,13-15,23)$, but there is no consensus regarding the best approach that includes therapeutic lifestyle changes as well as pharmacologic therapies. While further research is certainly warranted, so too are clinical and health policy measures (24-29).

In this issue of the journal, new predictors of metabolic syndrome in children, epidemiology of childhood obesity, and the relation to subsequent cardiovascular disease are addressed. All these issues underscore the crucial need for primary prevention of obesity in children throughout the world.

\section{REFERENCES}

1. Ogden CL, Carroll MD, Curtin LR, McDowell MA, Tabak CJ, Flegal KM 2006 Prevalence of overweight and obesity in the United States, 1999-2004. JAMA 295:1549-1555

2. Ogden CL, Flegal KM, Carroll MD, Johnson CL 2002 Prevalence and trends in overweight among US children and adolescents, 1999-2000. JAMA 288:1728-1732

3. Nader PR, O'Brien M, Houts R, Bradley R, Belsky J, Crosnoe R, Friedman S, Mei Z, Susman EJ 2006 Identifying risk for obesity in early childhood. Pediatrics 118:594-601 
4. Lissau I, Overpeck MD, Ruan WJ, Due P, Holstein BE, Hediger ML and the Health Behaviour in School-aged Children Obesity Working Group 2004 Body mass index and overweight in adolescents in 13 European countries, Israel and the United States. Arch Pediatr Adolesc Med 158:27-33

5. Kolata G 1998 Obesity's link to early death found less than suspected. The New York Times (January 1, 1998)

6. World Health Organization 2000 WHO Technical Report Series 894: Obesity: Preventing and Managing the Global Epidemic. A report of a WHO consultation, Geneva Available at: http://www.iotf.org/policy.asp Accessed on 1/7/07

7. Caterson ID, Hubbard V, Bray GA, Grunstein R, Hansen BC, Hong Y, Labarthe D, Seidell JC, Smith SCJr 2004 Prevention conference VII: obesity, a worldwide epidemic related to heart disease and stroke: Group III: worldwide comorbidities of obesity. Circulation 110:476-483

8. US Department of Health and Human Services 2001 The Surgeon General's call to action to prevent and decrease overweight and obesity. Public Health Service, Office of the Surgeon General, Rockville, MD Available at: http://www.surgeongeneral. gov/topics/obesity/calltoaction/CalltoAction.pdf Accessed on 1/7/07

9. Faith MS 2005 Development and modification of child food preferences and eating patterns: behavior genetics strategies. Int J Obes 29:549-556

10. Faith MS, Berkowitz RI, Stallings VA, Kerns J, Storey M, Stunkard AJ 2004 Parental feeding attitudes and styles and child body mass index: prospective analysis of a gene-environment interaction. Pediatrics 114:429-436

11. Mulvihill C, Németh A, Vereecken C 2004 Body image, weight control and body weight. In: Currie C, Roberts C, Morgan A, Smith R, Settertobulte W, Samdal O, Rassmussen, VB (eds.) Young people's health in context: international report from the HBSC 2001/02 survey. WHO Policy Series: Health policy for children and adolescents No. 4, WHO Regional Office for Europe, Copenhagen, pp 120-129 Available at: http://www.hbsc.org/publications/reports.html. Accessed on 1/7/07

12. Janssen I, Katzmarzyk P, Boyce W, Vereecken C, Mulvihill C, Roberts C, Currie C, Pickett W 2005 Comparison of overweight and obesity prevalence in school-aged youth from 34 countries and their relationships with physical activity and dietary patterns. Obes Rev 6:123-132

13. van Dam RM, Willett WC, Manson JE, Hu FB 2006 The relationship between overweight in adolescence and premature death in women. Ann Intern Med 145:91-97

14. Freedman DS, Khan LK, Dietz WH, Srinivasan SR, Berenson GS 2001 Relationship of childhood overweight to coronary heart disease risk factors in adulthood: The Bogalusa Heart Study. Pediatrics 108:712-718

15. Liu J, Wade TJ, Tan H 2007 Cardiovascular risk factors and anthropometric measurements of adolescent body composition: a cross-sectional analysis of the Third National Health and Nutrition Examination Survey.Int J Obes31:59-64

16. Fu J-F, Liang L, Zou C-C, Hong F, Wang C-L, Wang X-M, Zhao Z-Y 2007 Prevalence of the metabolic syndrome in Zhejiang Chinese obese children and adolescents and the effect of metformin combined with lifestyle intervention. Int $\mathrm{J}$ Obes 31:15-22

17. Chu N-F 2001 Prevalence and trends of obesity among school children in Taiwanthe Taipei Children Heart Study. Int J Obes 25:170-176

18. Hennekens CH 1998 Increasing burden of cardiovascular disease: current knowledge and future directions for research on risk factors. Circulation 97:1095-1102

19. Samdal O, Tynja J, Roberts C, Sallis JF, Villberg J, Wold B 2006 Trends in vigorous physical activity and TV watching of adolescents from 1986 to 2002 in seven European countries. Eur J Public Health Oct 28; [Epub ahead of print]. Available at: http://eurpub.oxfordjournals.org/cgi/content/abstract/ckl245v1. Accessed on 1/7/07

20. Hublet A, De Bacquer D, Valimaa R, Godeau E, Schmid H, Rahav G, Maes L 2006 Smoking trends among adolescents from 1990 to 2002 in ten European countries and Canada. BMC Public Health 6:280 Available at: http://www.biomedcentral.com/ 1471-2458/6/280. Accessed on 1/7/07

21. Robert Wood Johnson Foundation/AHA/American Stroke Association 2005 A nation at risk: obesity in the United States, statistical sourcebook. AHA National Center, Dallas, TX, p 3. Available at: http://www.americanheart.org/presenter.jhtml? identifier $=3030570$. Accessed on 1/4/07

22. Freedman DS, Dietz WH, Srinivasan SR, Berenson GS 1999 The relation of overweight to cardiovascular risk factors among children and adolescents: The Bogalusa Heart Study. Pediatrics 103:1175-1182

23. Singhal A 2006 Early nutrition and long-term cardiovascular health. Nutr Rey 64:S44-S49

24. Inge TH, Xanthakos SA, Zeller MH 2007 Bariatric surgery for pediatric extreme obesity: now or later? Int J Obes 31:1-14

25. Cassady D, Vogt R, Oto-Kent D, Mosiey R, Lincoin R 2006 The power of policy: a case study of healthy eating among children. Am J Public Health 96:1570-1571

26. Barlow SE, Trowbridge FL, Klish WJ, Dietz WH 2002 Treatment of child and adolescent obesity: reports from pediatricians, pediatric nurse practitioners, and registered dietitians. Pediatrics 110:229-235

27. Wojcjcki JM, Heyman MB 2006 Healthier choices and increased participation in a middle school lunch program: effects of nutrition policy changes in San Francisco. Am J Public Health 96:1542-1547

28. Harrell JS, McMurray RG, Gansky SA, Bangdiwala SL, Bradley CB 1999 A public health vs a risk-based intervention to improve cardiovascular health in elementary school children: The Cardiovascular Health in Children Study. Am J Public Health 89:1529-1535

29. Harper MG 2006 Childhood obesity strategies for prevention. Fam Community Health 29:288-298 